\title{
Ewa Wojciechowska
}

\section{Ciała otwarte, \\ ciała zamknięte \\ Pleć w dziewiętnastowiecznym dyskursie medycznym}

\section{Płeć pacjenta ma znaczenie}

Dziewiętnastowieczna literatura medyczna w zupełnie odmienny sposób opisuje chorych i chore, konkretne przypadki ujmując w konwencje, które wspieraja aktualna dystrybucję władzy: kobiety przedstawia w kostiumie histerycznym, podkreślając ich podległość prawom biologii, mężczyzn zaś stylizuje na racjonalnych, sprawczych bohaterów, utrzymujących nieustannie kontrolę nad własnym ciałem. W niniejszej pracy badam oddziaływanie przekonań na temat różnicy płciowej oraz wyobrażeń ideologicznych związanych $z$ kobiecością i męskością w literaturze medycznej $z$ lat czterdziestych XIX wieku (prasie specjalistycznej, rozprawach naukowych i popularyzatorskich, a zwłaszcza studiach przypad$\mathrm{ku}$; ograniczam się do tekstów publikowanych na terenie zaboru rosyjskiego). Zawężając podstawę materiałowa do dziesięciu lat, przyjmuję perspektywę mikrologiczną. Skupiam się na badaniu reprezentacji, dlatego $\mathrm{w}$ wielu miejscach adaptuję narzędzia litera-

Ewa Wojciechowska - doktorantka na Wydziale Polonistyki Uniwersytetu Jagiellońskiego. Zajmuje się prozą okresu romantyzmu. 
turoznawstwa: analizuje pozycję tego, kto opowiada, język, retorykę. Interesuje mnie, jaki efekt próbuja osiagać omawiani lekarze/ autorzy oraz jakimi środkami językowymi do niego dążą.

Fundamentalną opozycją, którą odnajduję w omawianym materiale, jest przeciwstawienie ciała zamkniętego, autarkicznego (przypisywanego mężczyznom) oraz ciała otwartego, podatnego na inwazję $z$ zewnattrz, przenikliwego i plastycznego (przypisywanego kobietom). Wiążą się $z$ tym dwie odmienne koncepcje choroby ${ }^{1}$ : rozumianej bądź jako brak, zachwianie równowagi (właściwe schorzeniom męskich pacjentów), bądź jako osobny, autonomiczny byt (odpowiadające chorobom kobiet). To właśnie przeciwieństwo: między ciałem zamkniętym i otwartym, dla których choroba jest odpowiednio zakłóceniem wewnętrznej równowagi bądź odrębnym, atakujacym $z$ zewnątrz organizmem, będzie stanowiła oś moich rozważań.

Zanim jednak przejdę do interpretacji poszczególnych chorób, zaczne od ustalenia, iż w przebadanym przeze mnie materiale pacjenci płci męskiej stanowią mniej niż jedną trzecią przypadków. Co znamienne, najczęściej są alkoholikami, więźniami, cierpią na choroby psychiczne. Przez to nie sa reprezentatywni dla ogółu mężczyzn, nie można tych wniosków rozszerzyć na wszystkich pacjentów płci męskiej. Mężczyzna częściej jest lekarzem niż pacjentem, dla kobiet zaś jest zarezerwowana ta druga rola.

Pierwsza dyplomowana polska lekarką była Anna Tomaszewicz-Dobrska, która w 1878 roku wróciła do Warszawy ze Szwajcarii, gdzie zdobyła dyplom. Mimo doktoratu (obronionego na podstawie rozprawy Przyczynek do fizjologii błędnika słuchowego) nie było jej łatwo stać się częścia środowiska naukowego. Znamienne jest tu uzasadnienie Warszawskiego Towarzystwa Lekarskiego dla odmowy przyjęcia Tomaszewicz do swojego grona, opublikowane na łamach czasopisma „Medycyna”:

\footnotetext{
1 Gdy mówię o definicji choroby, chodzi mi o jej ramy ideologiczne, jej konceptualizację. Warto przy tym zaznaczyć, że „do dziś nie potrafimy podać jednoznacznej i wyczerpującej definicji choroby". Historia medycyny, red. T. Brzeziński, Wydawnictwo Lekarskie PZWL, Warszawa 2000, s. 238.
} 
Zbadawszy dokładnie sprawę kobiet-lekarek, przychodzimy do przekonania, przede wszystkim, iż nie odpowiada ona żadnej naglącej potrzebie, gdyż lekarze mężczyźni najzupełniej celowi odpowiadają. Po wtóre, iż studiowanie medycyny i wykonywanie praktyki lekarskiej jest w wysokim stopniu nieodpowiednie ani usposobieniu, ani uzdolnieniu, ani charakterowi kobiet. Po trzecie, iż z małym wyjątkiem, wszystkie dzisiejsze lekarki lub kandydatki na takowe wypychane sa na tę fałszywa drogę nie przez zamiłowanie do nauki lub chęć poświęcenia się ludzkości, lecz przez jakieś awanturnicze usposobienie, przez chęć zabłyśnięcia czymś oryginalnym ${ }^{2}$.

Opinia nie tylko naturalizująca nieobecność kobiet wśród lekarzy, ale także dyskredytująca motywacje pierwszych lekarek (oraz sugestia, jakoby mężczyznami zawsze kierowało „zamiłowanie do nauki lub chęć poświęcenia się ludzkości”) wywołała burzę. O ile bowiem samo odrzucenie kandydatury Tomaszewicz mogło przejść bez echa, o tyle cytowana wypowiedź stała się przedmiotem żarliwej krytyki. Odzew nie doprowadził wprawdzie do zrewidowania decyzji Towarzystwa o odrzuceniu lekarki, ale utorował droge jej następczyni, Elżbiecie Downarowicz, która osiemnaście lat później jako pierwsza kobieta zasiliła to grono.

Gdy mowa o kobietach praktykujących medycynę w latach czterdziestych XIX wieku, nie możemy pominąc dwóch innych kontekstów. Po pierwsze, kobiety były akuszerkami. Wiadomość o stanie Wydziału Lekarskiego w Szkole Głównej Krakowskiej z 1842 roku wylicza dokładnie, jak wygląda procedura nadawania im patentu ${ }^{3}$. Wiadomo również o działalności wiejskich uzdrowicielek - znamy ją głównie $z$ potępiających głosów oficjalnej medycyny. Odblask tej krytyki znajdziemy nie tylko w naukowych tekstach medycznych, ale także w publicystyce, na przykład w satyrze Walerego Wielogławskiego Medycyna wiejska z $1859 \mathrm{roku}^{4}$. W utworze tym

\footnotetext{
2 Cyt. za: Z. Filar, Anna Tomaszewicz-Dobrska. Karta z dziejów polskich lekarek, Polskie Towarzystwo Historii Medycyny, Warszawa 1959, s. 14.

3 F. Skobel, Wiadomość o stanie Wydziału Lekarskiego w Szkole Głównej Krakowskiej za rządu austryackiego, Kraków 1842, s. 9.

${ }_{4}$ W. Wielogławski, Medycyna wiejska. Obrazek z obyczajów ludu wiejskiego, nakładem Księgarni i Wydawnictwa Dzieł Katolickich, Naukowych i Rolniczych, Kraków 1859.
} 
nad chorymi pochyla się szerokie grono (ksiądz, chłop, chłopka, pan, pani...), spośród nich to chłopka kumuluje w sobie wszystkie najgorsze cechy: złe intencje, skapstwo i głupotę, autor zaś piętnuje ją ustami księdza: „Wstydźcie się i bójcie się razem kary Pana Boga, iż nie słuchacie prawdy, którą wam kościół święty głosi, a słuchacie bajek i plotek, które diabeł przez głupie i złe baby po świecie rozsiewa [podkreślenie moje - EW]"5.

Ów obrazek potwierdza, że uzdrowicielki pełniły na wsiach ważna funkcję, mimo ostracyzmu, $z$ jakim się spotykały ze strony lekarzy. Jednak o nich oraz o stosowanych przez nich terapiach oficjalne pisma medyczne milcza. Toteż traktujac o reprezentacjach chorych ciał, zawartych w kanonicznym dyskursie medycznym, będę mówić głównie o kobietach oraz o leczących je mężczyznach.

\section{Otwartość}

Na początek chciałabym przyjrzeć się nie chorym ciałom, ale istotom, które mogły je zamieszkiwać w pierwszej połowie dziewiętnastego wieku. Obrazowego przykładu dostarcza doktor Michał Kaczkowski, opisując przypadek Praksedy Świętnej, wieśniaczki, lat 36, przedtem niechorujacej ${ }^{6}$. Pacjentka zaczęła cierpieć na bolesne torsje, na które nie pomagały żadne tradycyjne środki. Nie sposób też było zdiagnozować schorzenia dopóty, dopóki kobieta nie zaczęła wymiotować jaszczurkami. Kaczkowski połączył fakty - zmęczona praca i spragniona dziewczyna, pijąc wodę ze strumienia, musiała nieopatrznie połknąć złożone w niej jaszczurcze jaja. W ciepłym żołądku z jaj zaczęły się wykluwać gady. Sama diagnoza nie rozwiąywała jednak problemu, w jaki sposób można było ukrócić cierpienia kobiety. Jak zabić mieszkające w jej ciele jaszczurki, nie uszkadzając jednocześnie narządów wewnętrznych?

5 Ibidem, s. 15.

6 M. Kaczkowski, Jaszczurki $w$ ludzkim żoładku, „Pamiętnik Towarzystwa Lekarskiego Warszawskiego" 1841 , t. 5. 
Kaczkowski, niczym wytrawny powieściopisarz, umiejętnie dawkuje napięcie, prezentując kolejne kuracje (kalomel, olejek terpentynowy, olej kleszczowinowy). Szczegółowo i plastycznie opisuje reakcje ciała Praksedy na te środki („wypróżnienia stolcowe, podobne do białka zaczynającego krzepnaç"). W końcu, po zwróceniu około trzydziestu jaszczurek, pacjentka została wyleczona. Czytelnik może $z$ łatwością sobie wyobrazić, co się działo $z$ ciałem Praksedy, ale jednocześnie uderza go niesamowitość tej historii - wydarzenie wydaje się nieprawdopodobne, niemal baśniowe. Jakim cudem jaszczurcze jaja w takiej liczbie przetrwały w żoładku przez dwa tygodnie (tyle trwała niedyspozycja), niepoddane działaniu soków żołądkowych? Dlaczego nie zostały strawione? Pytania te zadał w komentarzu do opisanego przez Kaczkowskiego przypadku doktor Ignacy Lebel, zauważając, że to niemożliwe, sprzeczne $z$ ówczesna wiedza, ale jednocześnie podał dwa przykłady podobnego zjawiska - z Rosji i z Belgii. Co ciekawe, oba dotyczyły kobiet.

Piotr Szarejko wzmiankuje o omawianym studium Kaczkowskiego w Słowniku lekarzy polskich XIX wieku: „Artykuł pt. Jaszczurka w ludzkim żoładku, ogłoszony [w Pamiętniku Towarzystwa Lekarskiego Warszawskiego] w 1841 roku, stanowił curiosum oparte na zasłyszanych opowiadaniach" ". Sugestia, jakoby omawiany tekst był zasłyszana ciekawostka, nie daje się obronić: po pierwsze, sam Kaczkowski opisuje wydarzenia pierwszoosobowo, jako własne doświadczenie, i nie daje nigdzie do zrozumienia, jakoby coś relacjonował. Po wtóre, dokładnie przedstawia zastosowane środki zaradcze oraz ich skutki. Po trzecie, odpowiedź Lebla na ten przypadek nie jest analiza jakiegoś przesądu czy folklorystycznego podania. Przeciwnie, lekarz traktuje wyzwanie poznawcze, które przed nim stawia Kaczkowski, jako problem medyczny, nie etnograficzny, i ujmuje je w kategoriach diagnostycznych. Po czwarte wreszcie, Kaczkowski po obronie rozprawy doktorskiej opublikował

7 P. Szarejko, Słownik lekarzy polskich XIX wieku, t. 1, Towarzystwo Lekarskie Warszawskie, Warszawa 1991, s. 255. 
zaledwie cztery prace: nie był erudyta-polihistorem ani dyletantem wypowiadajacym się na rozmaite tematy.

Słowa Szarejki wyrażaja jednak sceptycyzm, którego nie sposób w tej sytuacji uniknać. Czy Prakseda Świętna naprawdę wymiotowała jaszczurkami? Pewne światło na tę sprawę może rzucić obserwacja Władysława Szumowskiego dotycząca histeryków:

Histerycy są obdarzeni nieraz dużą przenikliwością, sprytem i zręcznościa, których używaja $z$ powodzeniem, gdy pragna lekarza lub otoczenie wprowadzić w błąd, bo wymiotuja i wyrzucaja przez usta jakieś nieprawdopodobne przedmioty [podkr. moje - EW] i dopiero bardzo staranna obserwacja wykazuje, że chora ma w sukni ukryte to wszystko, co chce rzekomo zwymiotować ${ }^{8}$.

Szumowski łączy histerię $z$ zaburzeniami pracy układu pokarmowego, $z$ twardym, wzdętym brzuchem. Być może Prakseda była więc histeryczka - albo odreagowująca traumatyczne wydarzenie (o którym Kaczkowski milczy), albo $z$ premedytacja odgrywajacca scenę histeryczna, aby osiagnąć jakiś sobie tylko znany cel. Ponieważ mamy do dyspozycji jedynie narracje Kaczkowskiego, tej - ani żadnej innej - hipotezy nie możemy zweryfikować.

\section{Wystawione na spojrzenie}

Oczywiście, nie wszystkie przypadki sa równie dramatyczne i nieprawdopodobne, jednak to ciała kobiet częściej daja mieszkanie innym stworzeniom - a przynajmniej takie sytuacje sa częściej opisywane. Różnica płciowa dotyczy jednak również samej poetyki. Aby to zilustrować, omówię dwa opisy leczenia tasiemca: w pierwszym pacjentem jest kobieta, a w drugim - mężczyzna.

A.S., szesnastoletnia dziewczyna, uskarżała się na mdłości, drżenie serca i niespokojność, wezwany znalazłem ją tarzająca się po łóżku ze wzrokiem niespokojnym, źrenicami rozszerzonymi, ciepłem ciała naturalnym,

8 W. Szumowski: Historia medycyny filozoficznie ujęta, Sanmedia, Warszawa 1994, s. 280. 
pulsem prędkim, silnem biciem serca, oddechem krótkim, przytem było ciężkie wzdychanie, pot zimny, duszenie w gardle i nuda. Uważając robaki za przyczynę choroby, zaleciłem lewatywę $[\ldots]^{9}$.

Doktor Józef Pietraszkiewicz wysuwa ciało pacjentki na pierwszy plan, wystawia je niczym na scenie. To ono znajduje się w centrum uwagi; dzięki drobiazgowym opisom i wyliczeniom symptomów czytelnik może sobie je łatwo wyobrazić - zreszta, jest ono ujęte w znana, histeryczną konwencję.

W tym samym tomie znajdziemy inny przypadek, zatytułowany znamiennie $O$ wyjściu robaków przez ścianę brzuchowa. W nim ciało pacjenta-mężczyzny jest niewidoczne: choroba i terapia sa opisywane w taki sposób, że narrator koncentruje się na samym pasożycie, taktownie pomijając organizm gospodarza. Dosłownie raz, w końcowej partii tekstu, pojawia się wzmianka o „młodym człowieku", którego organizm zamieszkuje tasiemiec:

Teraz świeżo przed kilku laty profesor Siebold widział tasiemca żywego, który wyszedł $z$ obrzękłości koło pępka powstałej, u młodego człowieka, nieokazującego żadnych znaków przedziurawienia kiszek ${ }^{10}$.

Ciało mężczyzny jest zatem niewidoczne, przezroczyste dla tego języka - podczas gdy chore ciało kobiece i jego symptomy stanowia główny przedmiot drobiazgowego opisu. Choroba kobieca jest uprzestrzenniona, a jej ciało - widzialne. Porównajmy to $z$ przedstawieniem chorego mężczyzny, który cierpiał na rozdęcie tętnicy szyjnej, poddanego terapii głodówką i upuszczaniem krwi:

Był to chory w całej sile wieku, bo dopiero miał lat 36; poddał się temu sposobowi leczenia $z$ odwaga i poświęceniem, przetrwał go przez miesięcy trzy, lecz uleczył się zupełnie i do dnia dzisiejszego pełni obowiązki biurowe ${ }^{11}$.

\footnotetext{
9 J. Pietraszkiewicz, O leczeniu solitera, w: Praktyczne najnowsze postrzeżenia niektórych lekarzy, t. 1, red. A.F. Adamowicz, nakładem Rubena Rafałowicza, Wilno 1846, s. 66.

${ }^{10}$ A.F. Adamowicz, O wyjściu robaków przez ścianę brzuchowa, ibidem, s. 56.

${ }^{11}$ A. Le Brun, Uwagi o anewryzmatach prawdziwych, w szczególności o anewryzmie tętna podkolanowego, „Tygodnik Lekarski”, 2 września 1847, nr 10, s. 73.
} 
Doktor Aleksander Antoni Le Brun podkreśla tu aspekt wolicjonalny (poddał się, uleczył się) oraz cechy charakteru, które wiaża się ze słownikiem militarnym (odwaga, przetrwał) - ów chory pokonał swoje schorzenie. Zwykły urzędnik stał się w tej narracji krzepkim, wytrwałym żołnierzem ${ }^{12}$. Podczas gdy mężczyźni walcza $z$ choroba, kobiety biernie padaja jej ofiara. Ten sam lekarz, opisując przypadki wścieklizny, powołuje się jedynie na pacjentki. Zwróćmy też uwagę, że o ile, charakteryzując mężczyzn zmagających się $z$ choroba, podkreślał ich aktywność, kobietom przypisywał jedynie pasywność:

Chora ta czuła przystępujaca chorobe przy pierwszych jej zjawiskach, powiedziała mi, że się wścieka. Obok wstrętu do wody i rzeczy połysk wydających, znieść nie mogła najmniejszego powiewu chustki, przy czym wzdragała się, dostawała konwulsji, a przy dłuższym jej drażnieniu rzucała się na osobę powiewająca; chora ta pluła prawie nieustannie tak obficie, że podłoga w jej pokoiku była jakby zalaną. Gwałtowne bóle kurczowe w piersi i dławienie w gardle dokuczały jej najwięcej, po trzech dniach ciagłych męczarni wśród konwulsji zakończyła życie ${ }^{13}$.

Bierność i zawładnięcie pacjentką przez chorobę ukazuje też kolejny $z$ omawianych przez Le Bruna przypadków: „Na twarzy jej malowała się trwoga, oczy miała spuszczone w dół [...] cofała się [...] i zakrywała kołdra [...]"14. Pacjentka zatem totalnie utożsamia się ze swoja chorobą. Tym samym obraz chorej staje się obrazem choroby, który przedstawia się oczom lekarza. Dlatego też w ciałach kobiet schorzenia często współwystępuja: zapalenie płuc z zapaleniem wątroby, tyfus zamaskowany krwotokiem - w ten sposób eksponuje się kobiece ciało jako schorowana całość, podczas gdy mężczyzna ocala własna przedchorobowa tożsamość, nie zostaje zrównany ze swoja przypadłością.

\footnotetext{
${ }_{12}$ Jak pisze Susan Sontag, ten język wzmocni się wraz $\mathrm{z}$ odkryciem bakterii jako najeźdźców: „Metafora wojskowa w medycynie upowszechniła się w latach osiemdziesiatych dziewiętnastego stulecia po odkryciu bakterii jako czynników chorobotwórczych. Mówiono więc, że bakterie dokonuja inwazji lub infiltruja”. S. Sontag, Choroba jako metafora. AIDS i jego metafory, tłum. J. Anders, Wydawnictwo Karakter, Kraków 2016, s. 66.

${ }^{13}$ A. Le Brun, Wodowstręt (Hydrophobia), „Tygodnik Lekarski”, 19 sierpnia 1847, nr 8, s. 57.

${ }^{14}$ Ibidem.
} 
Gdy w latach czterdziestych XIX wieku pisze się o ortopedii i o mechanizmach korygujacych skrzywienia kręgosłupa, problem dotyczy jedynie kobiet i dziewczynek. To ich postawę modyfikuje się za pomocą specjalnych butów, wyciagów i stelaży. Skąd założenie, że takie bolesne korekty powinny dotyczyć głównie dziewcząt? Ponieważ ciało kobiece przedstawia się jako $z$ natury bardziej plastyczne i podatne - zarówno na chorobę (jak dowodza przywołane powyżej przypadki pacjentek, które chorobie poddaja się totalnie, nie stawiając - w przeciwieństwie do mężczyzn - bohaterskiego oporu), jak i na terapię. Widać to również w szeroko opisywanych przypadkach, gdy „wrażenia zmysły rażące”15 odciskają się w kobiecym ciele. I tak, mamy wiele przykładów ciąż mniemanych (urojonych). Przywołajmy ten paradygmatyczny: kobieta 23-letnia przestała miesiączkować, prawdopodobnie $z$ niedożywienia, a po ślubie $z$ bogatym wdowcem zaczęła tyć i uznała, że jest w ciąży. Sprowadziła akuszerki, z piersi „wyciska[1] się płyn do mleka podobny"16. Często również lekarze piszą o zapatrzeniach, kiedy w płodzie odciskają się wrażenia, jakich doznawała matka; jeśli na przykład długo patrzyła na drzewo wiśni - dziecko rodzi się z wiśniowym znamieniem na czole, gdy matce opowiadano o strasznej lalce bez członków, rodzi dziecko bez kończyn.

Wyłania się $z$ tego obraz kobiety kruchej, istoty o cienkich, nieszczelnych granicach, podatnej na niebezpieczne wpływy zewnętrzne, których nie potrafi powstrzymać, bezradnej i pasywnej ${ }^{17}$. Ocalić ja może jedynie interwencja lekarza - mężczyzny. Idealnym przykładem tej logiki jest pacjentka Paulina H., cierpiąca na dotkliwe bóle głowy. Przyczyna? $Z$ pewnością zewnętrzna - w jej czaszce „coś trzaskało” tak bardzo, iż odgłos ten słyszeli

\footnotetext{
${ }^{15}$ Zob. A. Helbich, O zapatrzeniu się niewiast brzemiennych, „Pamiętnik Towarzystwa Lekarskiego Warszawskiego" 1843 , t. IX.

${ }^{16}$ J. Moszyński, Cią̇̇a mniemana, w: Praktyczne postrzeżenia..., s. 68-72.

${ }_{17}$ Takie wyobrażenie kobiety było w XVIII i XIX wieku naturalizowane - w tym tonie wypowiadały się nawet same kobiety. Na przykład: „Przyrodzenie mocą obdarowało mężczyznę [...]. Czulszą i słabszą Bóg stworzył kobietę [...] jeżeli płeć męska włada światem, nasza go upiększa". K. z Tańskich Hofmanowa, Pamiątka po dobrej matce, nakładem Spółki Wydawniczej Księgarzy, Warszawa 1876, s. 310.
} 
nawet postronni. Oto głowę Pauliny zamieszkuje nieproszony gość, który, co gorsza, hałaśliwie się tam zachowuje i przysparza gospodyni cierpień. Pacjentkę wyleczono zimnymi kapielami. Przyczyny choroby nie odgadnięto.

\section{Męskość jako autarkia}

Wśród mnogości opisywanych przypadków męskie choroby sa rzadkością. Reprezentuje się je w dwóch biegunowo odmiennych, acz komplementarnych trybach. Pierwszy ilustruje przypadek opisany w 1841 roku na łamach „Pamiętnika Towarzystwa Lekarskiego Warszawskiego": młody oficer pije w łaźni piwo, następnie wino, aż przechodzi go dreszcz. Wśród objawów znajduja się: „mocny ból w lewej stronie piersi, koło serca, goraczka, niepokój, tęsknota"18. Zwróćmy uwagę, jak te niemal poetyckie symptomy różnią się od opisywanych z fizjologiczna dokładnością symptomów kobiet, które przedstawiano w biologicznej, niemal naturalistycznej poetyce. Na tę przypadłość lekarz ordynuje upuszczanie krwi - metodę już wówczas wychodząca $z$ użycia i postrzegana jako archaiczną. Odwołuje się ona bowiem do humoralnej, hydraulicznej teorii choroby, w obrębie której zdrowie zależy od równowagi płynów w ciele. Kiedy te zbyt gęstnieja lub gdy jest ich za dużo, harmonia zostaje zachwiana. Aby ją przywrócić, należy właśnie upuścić nieco krwi. I faktycznie, pacjent momentalnie wraca do zdrowia - choroba była dla niego chwilowym i jednorazowym zaburzeniem. Jest to podobny przypadek do przywoływanego wyżej pacjenta, który dzielnie stawił czoła opuchnięciu żył i wrócił do swoich zajęć: choroba zachwiała na chwilę jego organizmem, a po redukcji zakłócenia nic się w stosunku do sytuacji wyjściowej nie zmieniło.

Drugi pacjent, 44-letni Franciszek Okulicz, były więzień, przyjęty do szpitala Braci Miłosierdzia z diagnozą: „silne paroksyzmy ze

18 J. Lebel, Zdanie sprawy z czynności Towarzystwa Lekarskiego Warszawskiego, „Pamiętnik Towarzystwa Lekarskiego Warszawskiego" 1841, t. 5. 
wściekłościa połączone" $\mathrm{w}$ ogóle nie reaguje na terapie ${ }^{19}$. Maść merkuriuszowa, pijawki, zimne kapiele, lewatywy - nic nie pomaga. Ze szpitala Franciszek regularnie ucieka, po czym, łapany przez policję, wraca do kliniki, gdzie przechodzi kolejne nieskuteczne kuracje, aż do momentu, gdy ponownie nie uda mu się uciec. Po kilku latach powtarzania tego cyklu pacjent umiera. I choć pozornie to sytuacja bardzo odmienna od tej, która się przydarzyła pacjentowi $z$ bolącym sercem, to coś ich łączy: obaj mężczyźni nie zmienili się pod wpływem terapii - pozostali tymi, kimi byli. Pierwszego upuszczenie krwi przywróciło do stanu uprzedniej równowagi, ciało drugiego zaś było oporne na wszelkie interwencje. Obaj pozostali niezmienni aż do śmierci. O ile więc ciała kobiece przedstawiano jako bardzo podatne i plastyczne - przez pryzmat tego, jak wchodza one $\mathrm{w}$ relację ze światem zewnętrznym, który na nie oddziałuje o tyle ciała męskie pokazuje się jako niewrażliwe na bodźce zewnętrzne i zamknięte, przypominające ufortyfikowaną twierdzę.

Podobne wyobrażenie mężczyzny-pacjenta jest uniwersalne dla dziewiętnastowiecznej wyobraźni: język medycyny utrwala i aktywnie kształtuje ideologię różnicy płciowej. Agnieszka Gromkowska-Melosik wymownie pokazuje tę ideologię, zestawiajac dwa dziewiętnastowieczne dzieła malarskie podejmujące tematykę choroby i terapii. Pierwszym jest obraz Roberta Cutlera Finkleya Pierwsza operacja $z$ użyciem eteru, na którym pacjentem jest mężczyzna:

W szpitalnym amfiteatrze na kolejnych stopniach siedzą mężczyźni, którzy - w doniosłym medycznym spektaklu - przyglądaja się zabiegowi (wycięcie guza $z$ szyi). Po lewej stronie widzimy pozostającego bez ruchu pacjenta - mężczyznę (dwudziestoletniego Edwarda Gilberta Abbotta), który pod wpływem eteru nie odczuwał bólu. Patrząc na niego, nie potrafię uwolnić się od wrażenia, że godnie spoczywa on na chirurgicznym krześle, jakby pełen powagi i przekonania o znaczeniu wydarzenia, w którym uczestniczy, dla przyszłości medycyny. Oto racjonalny pacjent i pełni medycznej racjonalności - ubrani w ciemne garnitury - mężczyźni, którzy $z$ uwaga i zaangażowaniem obserwują rozwój wydarzeń. Pacjent jest przedmiotem medycznego działania, ale ma się wrażenie, że jest też

${ }^{19}$ Praktyczne najnowsze postrzeżenia..., t. 1, s. 9. 
w pewien sposób podmiotem tworzacym dzieje chirurgii - jest pacjentem, którego się szanuje, a obecni na sali są świadomi, że uczestniczą w tworzeniu historii medycyny (po udanym, trwającym dwadzieścia pięć minut zabiegu pacjent oznajmił, że nie czuł bólu, co zgromadzona widownia przyjęła $z$ wielkim entuzjazmem) ${ }^{20}$.

Porównajmy to płótno $z$ Wykładem klinicznym $w$ Salpêtrière pędzla André Brouilleta, na którym pacjentka jest kobieta:

Spektakl medycyny i spektakl kobiecości. Dla dwudziestu ośmiu mężczyzn w czarnych garniturach i białych koszulach, patrzacych spokojnie, z zainteresowaniem; uosabiających wiedzę i prawdę medycyny, psychiatrii. Uosabiających władzę męskości nad ciałem i tożsamościa kobiety. Charcot [lekarz - EW] jest mistrzem ceremonii. Oto egzemplifikacja i potwierdzenie androcentrycznego świata. Bez watpienia kobieta stanowi centrum obrazu - jest spektaklem, jednak jedynie takim samym spektaklem jak bohaterki niekończących się konkursów piękności. Jest zdefiniowana przez mężczyzn i dla mężczyzn ${ }^{21}$.

Konfrontacja tych dwóch obrazów pokazuje wymownie, w jaki sposób medycyna powtarza i reprodukuje tradycyjne wyobrażenia o różnicy płciowej, jak rysuje się opozycję między tym, co męskie (aktywne, autarkiczne, wolne, niezależne, racjonalne) a tym, co kobiece (bierne, podległe, niesamodzielne, podatne na wpływy, cielesne, biologiczne). $Z$ tą różnicą wiążą się również dwa odmienne sposoby postrzegania choroby. W wypadku kobiet choroba przychodzi z zewnatrz - jak robak, jaszczurka, tasiemiec, silne wrażenie, wścieklizna od zarażonego zwierzęcia czy nieznani intruzi zamieszkujacy czaszkę Pauliny H. Pacjentka choruje w wyniku przepuszczalności granicy między Ja a światem, między wnętrzem a zewnętrzem, chorobie zaś przyznaje się tu byt autonomiczny. $Z$ kolei w wypadku mężczyzn schorzenie ma charakter zaburzenia równowagi, zakłócenia, nie zaś samodzielnego bytu. Pacjent nie podlega wpływom zewnętrznym.

${ }^{20}$ A. Gromkowska-Melosik: Kobieta epoki wiktoriańskiej. Tożsamość, ciało i medykalizacja, Oficyna Wydawnicza „Impuls”, Kraków 2013, s. 23-24.

${ }^{21}$ Ibidem, s. 26. 


\section{Historia medycyny jako historia sporu o status choroby}

Historię medycyny można opowiedzieć z perspektywy tego, jak traktowała chorobę: czy postrzegała ja jako wtargnięcie obcego bytu w ciało człowieka (a tym samym ów byt stanowiłby odrębny, autonomiczny organizm), czy też uznawała ja za brak lub zaburzenie w ciele. Jednocześnie nie jest to historia linearna, opowiadajaca o przejściu od jednego paradygmatu do drugiego: te dwa obrazy ścieraja się ze sobą, rywalizują o uznanie w głównym obiegu. W historii medycyny znajdujemy też wiele rozbieżności między teoria a praktyka - na przykład między postrzeganiem choroby jako kary Bożej a działaniami terapeutycznymi opartymi na empirii. Wielokrotnie też widać w niej konflikt między medycyną oficjalna a nieoficjalną - ludową, często uprawianą przez kobiety. Dobitnym świadectwem tego stanu rzeczy są słowa Paracelsusa, który publicznie rzucając w ogień księgi Galena i Awicenny (zapewne na fali obrazoburczych spaleń dokonywanych w tym czasie przez Marcina Lutra) deklarował, że woli medycyny uczyć się od czarownicy i kata niż od kształconych medyków ${ }^{22}$. Przyjrzyjmy się jednak $z$ historycznego punktu widzenia tej zarysowanej przeze mnie opozycji.

Już dawna medycyna hinduska i chińska mówiły o chorobie jako o zaburzeniu równowagi: „Człowiek jest zdrów wtedy, jeżeli yin i yang sa $\mathrm{w}$ nim $\mathrm{w}$ równowadze i jeżeli wszystkie pierwiastki sa we właściwym stosunku, w przeciwnym wypadku występuje choroba"23. Hipokrates dostarcza najbardziej wyrazistej definicji tego poglądu: w jego teorii harmonia jest naturalnym stanem organizmu, który ma ogromne zdolności samoleczenia. Natura, physis, która jest celowa i racjonalna, sama leczy, dążąc do przywrócenia zachwianej równowagi między płynami w ciele: „Gdy ciecze są w porządku

${ }^{22}$ W. Szumowski, Historia medycyny..., s. 293.

${ }^{23}$ Ibidem, s. 48. 
i żadnej $z$ nich nie ma za dużo ani za mało i sa dobrze $z$ soba zmieszane (z gr. eukrasia), wtedy człowiek jest zdrów. Gdy są źle zmieszane ( $z$ gr. dyskrasia) albo jednej jest za dużo lub za mało, wtedy człowiek jest chory"24. Dlatego lekarz ma przede wszystkim obserwować naturę i jej pomagać, a nie interweniować samodzielnie, na własna rękę, przeciw naturalnym procesom reparacji.

Myśl Hipokratesa kontynuuje Eristratos, który chorobę nazywa „pomyłka miejsca” (łac. error loci): bierze się ona $z$ tego, że coś w ciele jest nie na miejscu. Żołądek i jelita przepełniają się nadmiarem jedzenia, żyły przepełniają się krwią, stawy - złogami; wyrasta guz, wytwarza się zapalenie ${ }^{25}$. Tę tradycje - patologię humoralna i teorię error loci - przejmie potem Galen. Mit o chorobie jako o skażeniu soków czy ich niewłaściwej mieszaninie owocuje praktyka puszczania krwi, która w różnych formach utrzymywała się do XIX wieku. Do hipokratejsko-galenowskiego rozumienia choroby jako zakłócenia równowagi średniowiecze dodało nacisk na czystość. W XVII wieku wciąż powszechnie stosowano głodówki, środki przeczyszczające czy upuszczanie krwi, traktowane jako zabiegi higieniczne, wspierajace naturalne procesy regulacji ciała ${ }^{26}$. Zgodnie $z$ tendencja mechanicystyczna organizm przedstawiano jako ciag rur: „To wyobrażenie, związane $z$ ówczesnymi technikami hydraulicznymi, uprzywilejowuje tradycyjne poczynania oczyszczajace" ${ }^{27}$. W tej teorii człowiek jest autarkiczną całością, która może ulec lokalnej destabilizacji przez zaburzenie hydrauliki, nazywane chorobą. Wystarczy przeczyścić system, aby przywrócić harmonię i równowage, czyli zdrowie.

Obraz przeciwstawny, traktujący chorobę jako coś autonomicznego i zewnętrznego, występuje w dwóch odmiennych wersjach: transcendentnej (w której schorzenie to kara Boża, przychodząca spoza tego świata) lub immanentnej (zgodnie $z$ która nie wiąże

\footnotetext{
${ }^{24}$ Ibidem, s. 83.

25 Ibidem, s. 102.

${ }^{26}$ G. Vigarello, Historia zdrowia i choroby. Od średniowiecza do współczesności, przeł. M. Szymańska, Niezależna Oficyna Wydawnicza, Warszawa 1997, s. 85.

27 Ibidem, s. 86.
} 
się bytu choroby $z$ jakąś boską instancją, ale raczej $z$ elementem świata rzeczywistego). Ten pierwszy wariant można dostrzec u starożytnych Babilończyków czy Greków (choć już Arystofanes w Plutosie kpi z oszustw kapłanów, którzy domagaja się ofiar za rytuały wypędzania choroby, spowodowanej rzekomo przez złego ducha) oraz w teoriach średniowiecznych, które widziały w chorobie karę. Szło za tym lekceważenie terapii:

Ponieważ trąd uchodził za chorobę nieuleczalna, leczenie nie zajmowało wybitnego miejsca $\mathrm{w}$ średniowiecznej historii tej choroby, zwłaszcza że leczenie choroby, którą uważano za dopust Boży, uchodziłoby za czyn zdrożny, za objaw pychy ludzkiej. Metody leczenia bynajmniej nie były i nie mogły być ustalone. Przynoszono jedynie chorym ulgę, opatrując zewnętrzne rany ${ }^{28}$.

Inną realizację tego modelu znajdziemy u Paracelsusa. Próbował on, odrzuciwszy uznane świętości dyscypliny (Galena i Awicennę), włączyć do medycyny kanonicznej jej nieoficjalny, podziemny nurt: „Szukał towarzystwa cyrulików, łaziebników, owczarzy, kowali, Cyganów, starych bab i od nich uczył się tajemnej sztuki leczenia"29. Jednocześnie podejście pragmatyczne czy empiryczne łączył $z$ panteistyczna metafizyka ${ }^{30}$, wedle której w każdym człowieku znajdował się archeusz, magiczna instancja, zdolna odpierać ataki $z$ zewnątrz. Choroba miała zatem polegać na opanowaniu archeusza przez obce potęgi duchowe, tak więc mowa tu o niemal spirytualistycznym rozumieniu niemocy. Według Paracelsusa człowiek jest podatny na czynniki zewnętrzne i musi $z$ nimi podjaćc wewnętrzną walkę. To wyobrażenie o zewnętrznym źródle choroby, powstałej w wyniku infekcji czy zakażenia, potwierdza doświadczenie epidemii dżumy. W XVI wieku Fracastor, lekarz z Padwy, nazywał żyjątka powodujące dżumę „zarodkami” (seminaria). Kon-

\footnotetext{
${ }^{28}$ W. Szumowski, Historia medycyny..., s. 271.

${ }^{29}$ Ibidem, s. 421.

${ }^{30}$ Interesująca wykładnię oryginalnego Paracelsiańskiego sprzężenia materializmu i spirytualizmu proponuje Marek Woszczek, Eliasz nauk. Apokaliptyka, paracelsjańska mistyka przyrody i narodziny nowoczesności (część pierwsza i druga), „Praktyka Teoretyczna” 2016, nr 1 (19).
} 
sekwencją epidemii był zatem lęk przed otwartym ciałem, ciałem przenikliwym (takim, które można przeniknąć, dostać się przez nie do środka). Bano się łaźni, wysiłku fizycznego, świeżego powietrza - wszystkiego, co otwiera ciało i rozszerza pory, umożliwiając wniknięcie jakiegoś obcego elementu ${ }^{31}$.

Jak wcześniej wspomniałam, te dwie wizje choroby koegzystuja ze soba. Już w średniowieczu obok wiary w działanie czynników nadprzyrodzonych pojawia się empiryczna świadomość, że choroby sa zaraźliwe oraz że powstaja przez kontakt osoby chorej ze zdrowa (te dwie wykładnie łączy jednak przekonanie, że choroba jest czymś zewnętrznym wobec ciała). Mimo mnogości alternatywnych koncepcji w praktyce leczono humoralnie do XVIII wieku; wiele sporów traktowano jedynie teoretycznie, podczas gdy terapia koncentrowała się na puszczaniu krwi, prowokowaniu przeczyszczeń i wymiotów oraz wzmaganiu potów - w celu wyrównania bilansu płynów w organizmie ${ }^{32}$. Fizjologia - podniesiona przez Albrechta von Hallera do godności nauki - miała zredukować instancje metafizyczne, zanieczyszczające naukowość dyskursu medycznego (takie jak physis Hipokratesa, pneuma Galena, archeusz Paracelsusa i Johanna Baptisty van Helmonta, tchnienia duchowe Kartezjusza czy dusza Georga Ernsta Stahla) do właściwości weryfikowalnych doświadczalnie (na przykład żywy mięsień zawsze reaguje na jakiekolwiek podrażnienie, ma więc cechę „drażliwości”, nerwy zaś charakteryzuja się zdolnością odczuwania, mają zatem cechę „czułości”). Równocześnie jednak von Haller sprowokował reakcję przeciwną: wysyp doktrynerów broniących metafizycznej koncepcji choroby (John Brown, Samuel Hahnemann, François Broussais, Franz Mesmer).

Na przełomie lat trzydziestych i czterdziestych XIX wieku znacznie się wzmogła dyskusja o statusie choroby. W 1837 roku na łamach „Pamiętnika Naukowego” ukazało się tłumaczenie artykułu Williama Cowpera O pojęciu choroby ze stanowiska filozofii natu-

${ }^{31}$ G. Vigarello, Historia zdrowia..., , s. 50.

${ }^{32}$ W. Szumowski, Historia medycyny..., s. 505. 
$r y^{33}$, w którym autor relacjonował przekrojowo historię medycyny $z$ punktu widzenia pojęcia choroby i doszedł do wniosku, iż nowoczesna medycyna skłania się ku uznaniu, że choroba stanowi byt autonomiczny. Badacz przedstawił rozmaite teorie medyczne wspierajace tę tezęę

- Paracelsusa: „Każda choroba ma ciało niewidzialne i jest członkiem wieloświata i drobnoświata, a nawet sama jest drobnoświatem i nibyczłowiekiem. Przeto człowiek $z$ chorobie składa się $z$ dwóch ciał, a przecież stanowi jedną osobę".

- Thomasa Sydenhama: „Choroba pochodzi ze szczególnego wygórowania pewnych części i spraw ciała ludzkiego do tego stopnia, iż osobne przedstawia życie lub ustrój pasożytniczy" (Cowper uważał Sydenhama za rzecznika teorii antyhipokratejskiej, choć przecież lekarza tego nazywano „angielskim Hipokratesem” i leczył on humoralnie).

- Melmonta: „Choroba jest rzeczywistościa istotna, złożoną z materii i siły wewnętrznej, która niejako gości w ciele. [...] Jest złem, ale niepodobnym do grzechu, bo ma nasilenie, postać i prawidła; nie jest odjęciem zdrowia, ale prawdziwa istota, żyje w życiu".

- Johna Starka: „Choroba nie różni się od życia, zatem sama jest życiem [...]. Nie jest brakiem, lecz szczególna forma życia, która wkracza w życie tego, co choruje".

Jednocześnie prowadzono badania nad granicami ludzkiego ciała oraz jego podatnością na bodźce; naczelnymi kategoriami były drażliwość lub irytacja. Rosła też popularność anatomii patologicznej oraz statystyki jako nowych źródeł wiedzy o chorobach. W ten sposób zrodził się nowy model w myśli medycznej, który Michel Foucault nazywa botanicznym: w nim choroby, podobnie jak wszystkie inne organizmy, sa gatunkami, to znaczy rosna, roz-

\footnotetext{
${ }^{33}$ W. Cowper, O pojęciu choroby ze stanowiska filozofii natury, thumacz nieznany, „Pamiętnik Naukowy" 1837, t. 2.

${ }^{34}$ Wszystkie przywoływane tu cytaty pochodza $z$ tekstu $O$ pojęciu choroby ze stanowiska filozofii natury (ibidem), nie sa wypowiedziami tych myślicieli, ale interpretacja cytowanego tekstu przez Cowpera.
} 
wijaja się i giną w jeden sposób, według właściwego im schematu. W ich cyklu życia widać regularność, nie przygodność ${ }^{35}$.

Doprowadziło to Cowpera do jednoznacznego wniosku: „Zniewoleni jesteśmy przyznać chorobie życie udzielne”. Skąd jednak ów przymus, to dyskomfortowe zniewolenie? Dlaczego Cowper - tak jak wielu innych lekarzy - odrzuca wizję ciała otwartego i podatnego, zamieszkiwanego przez inne, czasem nieproszone organizmy? Ponieważ oznacza nową antropologię - człowiek jest według niej gospodarzem, który nie kontroluje, kogo gości. Oznacza to odejście od archaicznej koncepcji choroby, zakładajacej silny, autonomiczny, harmonijny podmiot, w którego obrębie może się dokonać zachwianie równowagi. Tę dysharmonię może przywrócić do ładu sam organizm, własnymi siłami, $z$ niewielka pomoca lekarza. To wyobrażenie chorującego było zgodne $z$ przemijającym standardem hipokratejsko-galenowskim, wzbogaconym po 1816 roku o materialistyczne elementy ówczesnej medycyny francuskieje. W obrębie tego paradygmatu człowiek jest panem we własnym ciele - jak we własnym domu. Zastapił go model ciała otwartego na inne formy życia, w tym takie, które mu nie sprzyjaja, to znaczy ciała zamieszkiwanego przez inne organizmy. Tym samym choroba zaczęła być postrzegana nie tylko jako brak czy zakłócenie, ale jako autonomiczna, osobna forma życia. Najnowsze badania współbrzmią $z$ tą koncepcja - ciała jako otwartej przestrzeni koegzystencji. Współczesna mikrobiolożka i popularyzatorka nauki Alanna Collen ujmuje to obrazowo:

Jesteśmy zaledwie w 10 procentach ludźmi. Na każdą z komórek tworzacych to, co nazywamy swoim ciałem, przypada dziewięć obcych komórek,

\footnotetext{
${ }^{35}$ Zob. M. Foucault, Narodziny kliniki, thum. P. Pieniążek, Wydawnictwo KR, Warszawa 1999, s. 24-25.

${ }^{36}$ B. Płonka-Syroka, Medycyna niemiecka nurtu niematerialistycznego 1797-1848 i polska recepcja jej teorii doktryn $w$ dziewietnastym stuleciu, Wydawnictwo DiG, Warszawa 1999, s. 395. Pragnẹ podkreślić, iż piszę tu o dziewiętnastowiecznym rozumieniu galenizmu. Należy tu zaznaczyć osobna, interesująca kwestię, dotycząca tego, w jaki sposób nowożytna, mechanicystyczna filozofia modyfikuje przednowoczesna medycynę, której używa do legitymizacji własnej pozycji. Wątpliwe, by sam Galen mógł się zidentyfikować z siedemnasto-, osiemnasto- czy dwudziestowiecznymi galenistami.
} 
które się na nas tylko „wożą". Nie jesteśmy tylko mięśniami, kośćmi, krwia, mózgiem i skórą, lecz także bakteriami i grzybami. Jesteśmy bardziej „nimi” niż „soba”

Collen używa nawet pojęcia superorganizmu - kolektywu gatunków żyjących ramię $\mathrm{w}$ ramię i wspólnie sterujących ciałem. Dziś to wiedza popularna.

W latach czterdziestych XIX wieku nie znano jeszcze bakterii i pasożytów, które bezspornie potwierdzaja teorię człowieka jako gospodarza oraz autonomicznego bytu choroby, ale podejrzewano ich istnienie. Mikroskop odkryto już w XVII wieku, w 1847 roku węgierski położnik Ignaz Semmelweis zaobserwował, jak lekarze przenoszą goraczkę połogowa na nieumytych dłoniach $z$ prosektoriów do sal szpitalnych. Dopiero jednak dwadzieścia lat później Ludwik Pasteur opracował teorię przypisujacca infekcje mikrobom. Stało się wówczas jasne i niepodważalne, że choroba przychodzi $z$ zewnatrz.

\section{Kobieta: groźna nowoczesność}

Jest interesujące, że wyobrażenia o chorobach kobiet i mężczyzn odzwierciedlaja również historyczne przemiany medycyny oraz zmiany rozumienia pojęcia choroby. Choroby mężczyzn przedstawia się zgodnie $z$ tradycyjnym paradygmatem humoralnym, podczas gdy schorzenia kobiet - według tryumfujacej $\mathrm{w}$ nauce definicji choroby jako bytu autonomicznego, zewnętrznego wobec pacjenta. Innymi słowy, obraz nowoczesności (groźnej, budzącej lęk, bo związanej z zachwianiem poczucia niezależności i autarkii Ja) nakłada się na obraz kobiety. Nie zapominajmy też, że rozwój medycyny przyczynił się do dziewiętnastowiecznego kryzysu męskości: medykalizacja zaczęła bowiem dotykać nie tylko kobiecych,

\footnotetext{
${ }^{37}$ A. Collen, Cicha władza mikrobów, tłum. R. Palewicz, Wydawnictwo Bukowy Las, Wrocław
} 2016, s. 9. 
ale także męskich ciał, w związku $z$ czym także one zaczęły być postrzegane jako kruche i podatne na zranienie ${ }^{38}$. O zaistnieniu nowej modalności opisu mężczyzny - opisu skoncentrowanego na ciele, ukazującego poddanie się emocjom, rozedrganego i słabego - świadczy literatura piękna, często podejmująca temat zagrożenia „zniewieścieniem” i „utratą męskości”39.

Męskie ciało, jak pisze George Mosse, odzwierciedla pragnienia mieszczańskiego społeczeństwa - porządek, ład, samokontrolę, racjonalnośćc ${ }^{40}$. Aby mogło pełnić tę rolę, kobieta musiała być od niego radykalnie różna. Fantazja o dopełniających się, niczym dwie połówki pomarańczy, kobiecości i męskości to też wyobrażenie o tym, że istnieje między nimi nieprzekraczalna granica. Nic zatem dziwnego, że wstępowanie kobiet w męskie dziedziny życia wywoływało lęk - naruszało bowiem sterylną, normatywną męskość, uosabiająca usystematyzowany mieszczański świat.

Nakładanie obrazów nowoczesności i kobiecości w dyskursie medycznym (łącznie $z$ irracjonalnym wyobrażeniem wymiotowania jaszczurkami, które przywołałam na początku), lęk przed zniewieścieniem i zachwianiem granicy między płciami to symptomy szerszego zjawiska - dziewiętnastowiecznego kryzysu męskości, który odreagowywano w nienawiści wobec kobiet oraz ich utożsamianiu ze straszna, destrukcyjna nowoczesnościa, z płynna modernitas, w której dotychczasowy stabilny porządek społeczny ulega zachwianiu. Wymowny przykład znajdziemy w liście Zygmunta Krasińskiego do Henryka Reeve'a z 11 grudnia 1831 roku, w którym pisze o słynnej pomywaczce $z$ Ferney. Dziewczyna, krzepka i o „tygrysim sercu”, wypowiada następujące słowa: „Dawno nam

\footnotetext{
${ }^{38}$ Więcej na ten temat zob. Ch. Firth, Masculinity in the Modern West, rozdział Modern Primitives, Palgrave Macmillan, Houndmills, Basingstoke 2008.

${ }^{39}$ Temat ten został wyczerpujacco opisany w książkach Mateusza Skuchy i Tomasza Kaliściaka. Zob. M. Skucha, Ładni chłopcy i szalone. Męskość $i$ kobiecość $w$ późnym pisarstwie Józefa Ignacego Kraszewskiego, Collegium Columbinum, Kraków 2014; T. Kaliściak, Płeć pantofla. Odmieńcze męskości w polskiej prozie XIX i XX wieku, Wydawnictwo Instytutu Badań Literackich PAN, Warszawa 2016.

${ }^{40}$ G.L. Mosse, Image of Men. The Creation of Modern Masculinity, Oxford University Press, New York - Oxford 1996, s. 9.
} 
już obiecuja równość w niebie; niech się wpierw zacznie na ziemi. [...] Dalibóg, każdemu coś się należy, na każdego przychodzi kolej. [...] pora już, byśmy zajęły wasze miejsca. Jak długo na nich siedzicie?”11. Zniesmaczony Krasiński komentuje:

[...] to kobieta przyszłości, kobieta emancypowana, o której marza dzisiejsi szatańscy utopiści. Nie trzeba jej już będzie wspierającego ramienia mężczyzny, ale i dla jego serca przestanie być bóstwem; mocna, muskularna i namiętna, $z$ równa łatwością będzie zabijać i rodzić. Zerwie zasłonę wstydu, a jej wdzięki zwyrodnieja, aż stanie się twarda i prostacka. Niezachwiana i pewna siebie, iść będzie swoja droga, nie trwożąc się i nie potykając, ale krzycząc i perorując, gadając o państwach i ludach, wymyślając systemy i maszyny parowe. Wieczna hańba tym, którzy chca ją do tego doprowadzić, którzy chca, by anioł zszedł do rzędu ludzi $[\ldots]]^{42}$

Krasiński dostarcza modelowego przykładu rozumowania, zgodnie $z$ którym emancypacja kobiet wiąże się $z$ wielka rewolucja i rozpadem ładu świata, co pogrąża wszystkich w chaosie, a tym samym wpisuje się w długa tradycję: „[...] kryzys wartości, jaki towarzyszy niepożądanym zjawiskom i procesom modernizacji, od dawna artykułowany jest jako problem płci i rodzaju", wyraża się w przekonaniu, że „[...] kobieta i to, co żeńskie, wcielają nienawistne tendencje nowoczesności" ${ }^{43}$.

Ów lęk przed degeneracją kultury, która dokona inkulzji i zrównania nowych uczestników, był również lękiem przed kobieca emancypacją na poziomie politycznym, przed tym, że żądające praw kobiety swoimi roszczeniami uszczupla pulę męskich przywilejów. Dlatego mężczyźni - a wśród nich lekarze, ci sami lekarze, którzy tak panicznie bali się przyjęcia w swoje szeregi kobiet - uznali za stosowne przede wszystkim odebranie kobietom prawa głosu. A lata czterdzieste XIX wieku, na których koncentruję się $\mathrm{w}$ tym

\footnotetext{
${ }^{41}$ Z. Krasiński, Listy do Henryka Reeve, t. 1, list z 18 grudnia 1831 roku, przeł. A. Olędzka-Frybesowa, oprac. P. Hertz, Państwowy Instytut Wydawniczy, Warszawa 1980, s. 636.

42 Ibidem, s. 638.

${ }^{43}$ N. Gładziuk, Pesymizm kulturowy i heroiczna męskość, „Kultura i Społeczeństwo” 2014, t. 58, nr 1 , odpowiednio s. 3 i 4.
} 
tekście, to czas wystapień entuzjastek; Narcyza Żmichowska, Bibianna Moraczewska, Wiktoria Lewińska, Faustyna Morzycka i inne występowały wówczas na łamach pism opiniotwórczych, między innymi „Pierwiosnka” (1838-1843), „Pielgrzyma” (1842-1846) i „Przeglądu Naukowego” (1842-1848). Obraz kobiety biernej, reaktywnej, niezdolnej do obrony i zmuszonej do polegania na męskim autorytecie można rozumieć jako reakcję na coraz śmielsze głosy entuzjastek oraz innych działaczek sprawy kobiecej.

Opisana przez doktora Michała Kaczkowskiego historia Praksedy rezonuje ze znana ludową baśnią o dwóch siostrach ${ }^{44}$ : jedna - dobra, cicha i posłuszna - waloryzowana jest pozytywnie, druga zaś - egoistyczna i niechętna do poświęceń - stanowi postać negatywna. W bajce obie dziewczynki wybieraja się do chatki karzełków, w której zostają wystawione na próbę: karzełki chca, aby dziecko sprzatało im w domu i oddało swoja porcję chleba. Dobra dziewczynka skwapliwie wykonuje polecenia i w nagrodę zostaje obdarzona cudowna mocą: gdy tylko otwiera usta, wypadaja $z$ nich diamenty. Jej zła siostra, zobaczywszy tę umiejętność, także pragnie ja posiasść, idzie do chatki karzełków, ale ani myśli spełniać ich prośby. Nie sprząta im w chatce, nie dzieli się jedzeniem, czeka natomiast na nagrodę. Jak łatwo się domyślić, karzełki zgotowały jej dotkliwa karę: gdy otwiera usta, wypadaja $z$ nich żaby i jaszczurki - dokładnie tak jak w relacji Kaczkowskiego.

Ta bajka komunikuje dziewczętom dwa ostrzeżenia: po pierwsze, że jeśli wyjda poza normatywny model posłuszeństwa, spotka je straszliwa kara, nagroda zaś za realizowanie męskich poleceń jest akceptacja ze strony innego mężczyzny (księcia, który zakochuje się w dobrej dziewczynie) lub w diamentach, które wypadaja $z$ jej ust. Oprócz socjalizacji do posłuszeństwa bajka zawiera jeszcze drugie ostrzeżenie: że głos kobiety nie jest słyszany. W bajce obie dziewczynki staja się nieme: treść ich słów nie ma znaczenia, bo zagłuszaja ją diamentowe bąź żabie wymioty. Tak więc w latach czterdziestych XIX wieku, gdy kobiety domagają się głosu, mężczyźni

\footnotetext{
${ }^{44}$ Odwołuję się tu wersji skodyfikowanej przez braci Grimm pod tytułem Dary karzełków.
} 
w maskującym obiektywizm medycznym dyskursie opowiadają im nowoczesną wersję dawnej baśni o zamykaniu kobietom ust.

\section{Postscriptum. Od fortecy do ciała otwartego i z powrotem?}

W postrzeganiu choroby $\mathrm{w}$ latach czterdziestych XIX wieku można dostrzec ciekawy moment przejścia: wciąż żyje jeszcze, pozostająca w odwrocie, koncepcja humoralna, związana $z$ autarkicznym podmiotem (i ona właśnie jest zarezerwowana dla mężczyzn - nie opisuje się kobiet $\mathrm{w}$ tym trybie), ale podmiot ten zostaje już wystawiony na wpływy zewnętrzne, dlatego ciało mężczyzny staje się odporne i ufortyfikowane - nacisk kładzie się właśnie na rozmaite strategie obrony i oporu. Ogromne znaczenie dla tego obrazu ma nie tylko odkrycie bakterii przez Pasteura, ale także odkrycie systemu odpornościowego przez Ilję Miecznikowa w 1881 roku $^{45}$. Zasilaja one arsenał militarnych metafor: desygnujacych zarówno chorobę, jak i męskość. Stąd pojawia się retoryka wojny i odpowiedzialności, mówi się o człowieku jako kimś, kto bez przerwy zmaga się z groźnym, niewidocznym przeciwnikiem, nieustannie przypuszczajacym inwazję na mniej strzeżone granice ciała. Jej początki wiążą się właśnie $z$ odkryciem mikrobów, o których pisze się wówczas jak o „barbarzyńcach, którzy znaja tylko jedno prawo, prawo rozmnażania"46. Ten dyskurs będzie rósł w siłę, znajdujac wyraz w niemieckim faszyzmie czy narracji o AIDS w latach osiemdziesiątych i dziewięćdziesiątych XX wieku. Trzeba podkreślić, że obraz ciała podatnego i zamieszkiwanego nie ma tylko pozytywnego oblicza, o którym pisała Alanna Collen (superorganizm), ma także mroczny rewers, którym jest dyktat odpowiedzialności za siebie oraz przymus pilnowania granic ciała.

\footnotetext{
${ }^{45}$ Por. T. Kaliściak, Płeć pantofla..., s. 33.

${ }^{46}$ G. Dujardin-Beaumetz, L'hygiene propohylactique, cyt. za: G. Vigarello, Historia zdrowia..., s. 238 .
} 


\section{Open bodies, closed bodies: Sex in the nineteenth-century medical discourse}

The analysis of sexual differences in the representations of illnesses and patients in Polish medical literature in the 1840s shows that female and male patients were depicted in different ways. While female bodies were shown as open, vulnerable and malleable, male bodies were fortified, closed, and resistant. These two modes of representation entail two different concepts of illness: while women's illnesses were caused by external factors, men's maladies were believed to be the result of a distortion of inner balance. Interestingly, in the period discussed, there was more and more scientific evidence to support the 'feminine' concept of illness. Doctors projected the new vision of malady only on women, equating femininity and modernity and depicting them as dangerous forces disturbing the previous autarky of the men's world.

Keywords: medicine, sexual differences, female patients, male patients, concepts of illness. 